\title{
TRABALHADORES, ORGANIZAÇÕES E DISPUTAS POLÍTICAS NA ÚLTIMA DÉCADA DA PRIMEIRA REPÚBLICA
}

\author{
WORKERS, ORGANIZATIONS AND DISPUTES POLICY DURING THE 1920s
}

Philipe Murillo Santana de Carvalho*

\begin{abstract}
Resumo: O objetivo deste artigo é debater as relações políticas entre trabalhadores e suas organizações com intendentes, conselheiros municipais e deputados durante as eleições e atos públicos no sul da Bahia durante a década de 1920. Pretendo perceber como os sujeitos elaboraram suas ações na política coronelista, observando que apesar das forças políticas e econômicas originadas das oligarquias regionais, os trabalhadores podiam participar daquela experiência política no sentido de tirar suas vantagens para sobreviver e manter suas organizações. Diante destas experiências, refletir sobre o conceito de Coronelismo como parte das relações paternalistas em que a dominação não foi exercida sem participação e confrontação dos "de baixo". Como fontes, utilizei atas das entidades operárias do sul da Bahia, jornais de circulação regional, estatutos e atas dos poderes públicos de llhéus e Itabuna.
\end{abstract}

Palavras-chave: Trabalhadores, organizações e disputas políticas.

Abstract: The objective of this article is to discuss the political relations between workers and their organizations with stewards, local councilors and MPs during elections and public events in southern Bahia during the 1920s. I want to see how the subjects elaborate on their actions "coronelista" of political, noting that despite the political and economic forces that originate from local oligarchs, the workers could share that experience in order to take political advantages to survive and keep their organizations. In those experiences, reflects about the concept of "Coronelismo" as part of paternalist relations, who the domination didn't happened without participation and confrontation popular. As sources, I used the minutes of the entities operate in southern Bahia, regional newspapers, statutes and acts of public authorities llhéus and Itabuna.

Keywords: Workers, organizations, political disputes.

(recebido em 6 de outubro de 2011; aprovado em 3 de março de 2012)

O dia 12 de dezembro de 1920 foi marcado pelas solenidades de inauguração dos primeiros melhoramentos urbanos realizados sob a gestão do coronel José Kruschewsky à frente da Intendência Municipal de Itabuna. Tratava-se do calçamento da Praça Adami e da parte inicial da Rua Ruy Barbosa, ambos localizados na zona comercial, que segundo o registro da imprensa do partido do intendente, contribuiria "para um aspecto material empolgante da cidade". Como não poderia ser diferente, o poder público não se furtou de realizar uma solenidade marcada por elogios ao intendente, convidando para aquele evento várias entidades de classe, beneméritas e políticas, além da imprensa local. Entre as instituições presentes, estava a Sociedade Monte Pio dos Artistas de Itabuna representada por Flaviano Domingues Moreira, presidente da Assembleia Geral. Aliás, a agremiação dos artistas itabunenses cumpriria um papel importante naquela solenidade, isto porque Moreira não apenas assistiu, mas foi protagonista das

\footnotetext{
* Aluno de doutorado do Programa de Pós-graduação em História da UFBa. Professor do Instituto Federal da Bahia - campus Ilhéus. philipesantana@yahoo.com.br. Este artigo é resultado das pesquisas empreendidas no projeto Trabalhadores, política e cultura associativa no sul da Bahia (1920-1945). Agradeço em especial as contribuições dos colegas nos debates realizados na disciplina História Social, ministrada pela profa Gabriela Sampaio.
} 
inaugurações ao ser convidado pelo Cel. José Kruschewsky para cortar a fita que dava abertura ao novo calçamento da rua Ruy Barbosa1.

Logo após ter inaugurado oficialmente a obra pública, Flaviano Moreira pediu a palavra e proferiu um discurso em que se colocava como representante do operariado itabunense e comentava os trabalhos realizados pela intendência municipal. Dizia o líder do Monte Pio de Itabuna que sendo "legítimo intérprete do povo naquela festa, se sentia desvanecido por ter de cortar a fita que oferecia franco acesso àquela via pública, trabalho que já deveria se ter realizado, não fora a falta de patriotismo de outros administradores que antecederam o sr. Coronel José Kruschewsky, no governo"2. As comemorações continuaram em seguida com a inauguração de outras obras próximas, ainda acompanhadas pelos representantes dos artistas.

A participação da Sociedade Monte Pio na inauguração das obras da Intendência Municipal traz a necessidade de entender as formas com que as entidades de trabalhadores e as autoridades políticas construíram suas relações na década de 1920. O ufanismo e o enaltecimento do intendente coronel presente no discurso de Moreira sinaliza um esforço de se legitimar enquanto representante da classe trabalhadora de Itabuna, assim como estabelecer vínculos de reconhecimento político por parte do poder público em relação ao Monte Pio dos Artistas. Por outro lado, é importante notar a iniciativa por parte do coronel Kruschewsky em se aproximar de uma organização de caráter classista e incorporá-la no quadro de apoio do seu governo, dando-lhe papel importante. Portanto, tratava-se de um cenário em que grupos de origens sociais diferentes jogavam com seus interesses específicos, barganhando apoio político de ambas as partes. Isso fica mais evidente se voltarmos alguns meses no mesmo ano de 1920 e acompanharmos as ações políticas e sociais de autoridades políticas e de entidades trabalhistas neste período.

Quatro meses antes de promover as inaugurações dos melhoramentos públicos nas imediações da Rua Ruy Barbosa e da Praça Adami, foram realizadas eleições para intendente de Itabuna. Após períodos de afastamento da intendência municipal, Gileno Amado, líder do Partido Republicano Democrata (PRD), havia se afastado definitivamente do executivo para assumir o cargo de deputado federal no Rio de Janeiro. Com isso, a vaga de chefe municipal ficou interinamente ocupada pelo cel. José Kruschewsky, sendo necessário um novo processo eleitoral, agendado para agosto de 1920. Foi o mesmo Kruschewsky que surgiu como candidato único neste pleito pelo PRD, facção política liderada regionalmente por Amado e orientado pelo seabrismo no plano estadual. Apesar da candidatura única e da celebração no jornal $A$ Época

${ }^{1}$ CEDOC/UESC. Jornal A Época, 18/12/1920, ano IV, n.7. p. 1

2 Idem, Ibidem, p. 1. 
(órgão de imprensa do PRD) em face da previsível vitória eleitoral, há sinais de que o coronel não contava com tanto prestígio popular. Sobre isso, dizia o periódico em 29 de agosto que não houve grande comparecimento às urnas por parte do eleitorado naquele pleito ${ }^{3}$. Aproximar-se das entidades de trabalhadores deveria ser então uma tarefa a cumprir para 0 intendente municipal eleito.

Da parte dos trabalhadores, a década de 1920 consistiu em momento no qual eles conseguiram se organizar em entidades para se representarem nas disputas políticas e sociais. Exemplo disso foi a Sociedade Monte Pio dos Artistas de Itabuna. Fundada em novembro de 1919, esta agremiação buscou se fortalecer na cidade, atraindo artistas ${ }^{4}$ de vários ofícios em suas fileiras. Entre eles, haviam funileiros, marceneiros, ourives, alfaiates e tanoeiros, todos organizados no Monte Pio dos Artistas, entidade de caráter mutualista que visava "o benefício, 0 socorro, o auxílio mútuo, instrução moral e cívica, auxílio direto e indireto aos seus associados"5. Além desta associação, surgiram também o Grêmio Litero-Beneficente Caixeiral de Itabuna (1920) e a Sociedade União dos Ganhadores e Carroceiros de Itabuna (1924). Outras experiências nesse sentido ocorreram também em outras cidades, a exemplo de llhéus, onde também se formaram o Sindicato dos Estivadores do Porto de llhéus (1918), a Associação dos Empregados no Comércio de Ilhéus (1920), a União Protetora dos Artistas e dos Operários de Ilhéus (1922). Muitas destas associações eram mutualistas, cujo perfil de entidade era fundado numa cultura associativa de auxílio mútuo entre seus membros, protegendo-os da perda do emprego ou pagando pensão aos familiares em caso de morte. Algumas delas possuíam escolas para crianças filhas de artistas e de operários, filarmônicas e clubes recreativos ${ }^{6}$.

Era a partir destas organizações que os trabalhadores do sul da Bahia conseguiam se mobilizar e defender seus interesses frente aos poderes públicos e aos patrões. Isso nos faz retornar a inauguração dos melhoramentos urbanos em 1920, a qual contou com a participação da referida Sociedade Monte Pio. Àquela altura, o grêmio dos artistas de Itabuna havia completado pouco mais de um ano de funcionamento e buscava se firmar enquanto entidade representativa dos trabalhadores da cidade. Daí, então, a satisfação de Flaviano Moreira por ser convidado pelo intendente municipal para a inauguração das obras urbanas. Ainda cabe

\footnotetext{
3 CEDOC/UESC. Jornal A Época, 29/8/1920, Ano III, n.29. p. 1.

$4 \mathrm{O}$ termo artista se refere aos artífices profissionais que possuíam ofícios variados, como, por exemplo, sapateiro, alfaiates, ourives, pedreiro, tanoeiro.

${ }^{5}$ ASMPAI. Estatutos da Sociedade Monte Pio dos Artistas de Itabuna. 1919. pp. 1-2.

${ }^{6}$ FORTES, Alexandre. Nós do Quarto Distrito...: a classe trabalhadora porto-alegrense e a Era Vargas. Caxias do Sul, RS: Educs; Rio de Janeiro: Garamond, 2004. Para o autor, as associações mutualistas eram entidades que, mesmo de cunho assistencialista, estimulavam e canalizavam "práticas de solidariedade reforçando a identidade de classe", expressando "os desdobramentos de uma transformação estratégica na proposta de organização de uma minoria militante para a atração de massas".
} 
destacar que uma parte dos associados do Monte Pio morava ou possuía oficinas na rua calçada pela Intendência Municipal7. Além disso, fazer-se presente nas iniciativas do poder público significava estreitar laços com as autoridades políticas e abrir a perspectiva de obter alguns ganhos imediatos, conforme notaremos nas linhas à frente deste artigo.

Antes de continuarmos com as relações estabelecidas entre os grêmios laborais e as autoridades políticas da região sul da Bahia, cremos ser importante pontuar algumas reflexões e demarcar questões que perpassam este artigo. Do ponto de vista político, cabe refletir acerca da maneira com que a Primeira República ficou caracterizada no que tocas às relações políticas estabelecidas em torno do "mando" por parte das elites políticas e da "obediência" das classes subalternas. Para a historiografia que analisou a Primeira República, os ares republicanos são marcados pela forma com que a política foi exercida de modo unilateral, uniforme e autoritário, construída em uma estrutura que encurralava os "de baixo", ora assinalados como cidadãos de "cabrestos", "embrutecidos" ou "ignorantes"; ora assinalados como sujeitos que são reprimidos pelo Estado. Nesse sentido, cunhou-se o conceito de Coronelismo, utilizado por historiadores, sociólogos e cientistas políticos reforça a interpretação de que as oligarquias regionais controlavam a política a partir da sua expressão econômica .

Não se pode negar que muito do que teorizou Leal e Faoro sobre as relações de dominação política no Brasil da Primeira República é válido, especialmente se nos ativermos apenas ao exercício do poder institucional. Não faltam exemplos de como fazendeiros, industriais e comerciantes se utilizaram das redes de poder tecidas na democracia liberal republicana para ocupar os postos dos poderes públicos municipais e estaduais. Contudo, parece ter chegado a hora de nos perguntarmos até que ponto o conceito de coronelismo não tende a apresentar uma noção das relações políticas e da ordem social "visto de cima", em que

\footnotetext{
7 Informação extraída do ASMPAI. Livro de Matrícula da Sociedade Monte Pio dos Artistas de Itabuna. 1920-1945. APMIJD. Relação das Décimas Urbanas do Município de Itabuna. Jornal Oficial do Município de Itabuna. 1931.

8 LEAL, Victor Nunes. Coronelismo, Enxada e Voto: 0 município e o regime representativo no brasil. $2^{\mathrm{a}}$ Ed. São Paulo: Ed. Alfa-Ômega, 1975. Leal conceitua Coronelismo como "resultado da superposição de formas desenvolvidas do regime representativo a uma estrutura econômica e social inadequada. [...] É antes uma forma peculiar de manifestação do poder privado, ou seja, uma adaptação em virtude da qual os resíduos do nosso antigo e exorbitante poder privado tem conseguido coexistir com um regime político de extensa base representativa". (p. 20). FAORO, Raymundo. Os donos do poder. a formação do patronato brasileiro. $4^{a}$ ed. Porto Alegre: Globo, 1977. Para Faoro, o "coronel, antes de ser um líder político, é um líder econômico, não necessariamente, como se diz sempre, o fazendeiro que manda nos seus agregados, empregados ou dependentes. 0 vínculo não obedece a linhas tão simples, que se traduziriam no mero prolongamento do poder privado na ordem pública. Segundo esse esquema, o homem rico - o rico por excelência, na sociedade agrária, o fazendeiro, dono da terra - exerce poder político, num mecanismo onde o governo será o reflexo do patrimônio pessoal". (pp. 621-622).
} 
fundada numa interpretação generalizante, desenvolve-se a ideia de uma "sociedade de uma só classe", tal como afirmava Thompson na sua crítica ao conceito de paternalismo9 .

Se emprestarmos ao conceito de Coronelismo uma definição reduzida em uma ordem política centrada no mandonismo e na concentração de autoridade econômica, então produzimos um conhecimento histórico em que a agência dos "de baixo" desaparece e as relações sociais se tornam, de tão rígidas e sólidas, quase imutáveis. Portanto, adotar esta interpretação das práticas coronelistas menospreza a capacidade de populares, trabalhadores e subalternos em se organizarem em associações e partidos, de pressionar seus representantes políticos em face de suas demandas, assim como de ir à luta por seus direitos em campos institucionais e extra-institucionais, em agremiações ou, inclusive, prescindindo delas. 0 que se quer para este trabalho é procurar enxergar na experiência do coronelismo no sul da Bahia um jogo muito mais dinâmico e plural das disputas políticas e da ordem social. Desejamos pensar de que formas a constituição da classe trabalhadora na região se processou também em face da maneira como vivenciou e se apropriou da cultura política republicana da década de 1920. Se assim for feito, talvez notemos que para além da simples dominação, da manipulação de massas e da obediência civil, encontraremos trabalhadores como sujeitos ativos e atentos ao papel que Ihes cabiam no jogo político ${ }^{10}$.

No caso específico deste trabalho, o objetivo é compreender o envolvimento das organizações laborais do sul da Bahia com as autoridades políticas e seu papel no jogo eleitoral na década de 1920. Dentro do cenário político, quais as expectativas de intendentes, deputados e conselheiros municipais para com a classe trabalhadora da região? Do mesmo modo, o que os trabalhadores esperavam obter dos membros dos poderes públicos? Cabe, então, problematizar como se comportaram trabalhadores, políticos e patrões na conformação da luta de classes no eixo Ilhéus-Itabuna, colocando em foco como a questão social relativa aos trabalhadores foi tratada pelos últimos governos municipais da Primeira República. Para tanto, lançaremos mão de entender a experiência de trabalhadores e políticos durante campanhas eleitorais, eventos solenes das municipalidades e organizações trabalhistas.

\footnotetext{
9 THOMPSON, E.P. Costumes em comum: estudos sobre a cultura popular tradicional. Revisão técnica Antônio Negro, Cristina Meneguelo, Paulo Fontes, - São Paulo: Companhia das Letras, 1998. p. 28.

10 GOMES, Angela de Castro. A Invenção do Trabalhismo. Rio de Janeiro: Editora FGV, 2005. A autora sinaliza que o processo de constituição da classe trabalhadora em ator coletivo é um fenômeno político-cultural capaz de articular valores, ideias, tradições e modelos de organização através de um discurso em que o trabalhador é ao mesmo tempo sujeito e objeto.
} 


\section{Identidade, cultura associativa operária e relações políticas no sul da Bahia}

A década de 1920 foi marcada por muitas mudanças no cenário político estadual, as quais tiveram impacto direto na forma como as organizações trabalhistas lidavam com intendentes, conselheiros municipais e deputados. A cada eleição observamos a frequência da classe política no interior das sociedades operárias, promovendo palestras, banquetes e festas musicais promovidas pelas filarmônicas. Em contrapartida, os membros dos grêmios de trabalhadores não se furtavam de render homenagens para seus padrinhos políticos. No intervalo destas iniciativas estava em jogo os interesses de ambos os lados em garantir favores mútuos, desenhando uma rede de poder intricada entre trabalhadores e autoridades políticas.

Continuemos a acompanhar ainda o envolvimento da Sociedade Monte Pio dos Artistas de Itabuna e as autoridades políticas locais. Após ter participado das inaugurações do governo do cel. Kruschewsky, o grêmio dos artistas voltou a ter a atenção do intendente. Um exemplo disso foi um convite oficial para que o Monte Pio participasse das comemorações do centenário de Independência do Brasil na sede do Conselho Municipal em setembro de 1922. Naquela oportunidade, o chefe do executivo itabunense fez uma doação pessoal no valor de $500 \$ 000$ (quinhentos mil réis) para a compra de cimento e outros materiais que deveriam auxiliar no término da construção da sede social dos artistas ${ }^{11}$.

As contribuições do cel. José Kruschewsky para a Sociedade Monte Pio não pararam por aí. Após conversação com o intendente de Itabuna e o deputado Gileno Amado, em 1923, os artistas conseguiram

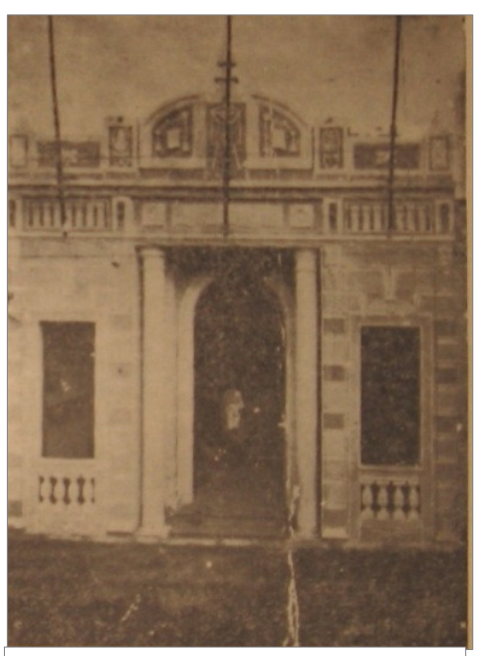

Figura 1- Sede social do Monte Pio dos Artistas, inaugurada em setembro de 1922. obter uma subvenção destinada a sua entidade, a qual deveria ser remetida para o pagamento de professoras que davam aulas na Escola Manoel Vitorino, instituição de ensino destinada à educação de crianças pobres e filhos de artistas associados ${ }^{12}$. Por sinal, não foi apenas a subvenção municipal que foi obtida com o contato de duas das autoridades políticas mais influentes de Itabuna. Gileno Amado também conseguiu uma subvenção federal para o Monte Pio dos Artistas. Em ata de 25 de maio de 1923, o deputado federal informava ao presidente da Assembleia Geral "que já havia assinado os documentos da subvenção federal para o Rio"13.

A obtenção destas subvenções públicas por meio da intervenção de políticos municipais e estaduais se tornou um dos meios mais eficazes de captar recursos para a sobrevivência de

\footnotetext{
${ }^{11}$ ASMPAI. Livro de atas da Assembleia Geral da SMPAI. Ata da 35a reunião ordinária. 17/9/1922. pp. 37v-38v. 12 ASMPAI. Livro de atas da Diretoria das SMPAI. Ata da $2^{\mathrm{a}}$ sessão ordinária da Diretoria. 21/1/1923. pp. 3-3v. ${ }^{13}$ ASMPAI. Livro de atas da Diretoria das SMPAI. Ata da $2^{\mathrm{a}}$ sessão ordinária da Diretoria. 23/5/1923. pp. 8-8v.
} 
entidades operárias no sul da Bahia. Aliás, esta não era uma peculiaridade do Monte Pio de Itabuna, pois outros grêmios trabalhistas que criaram bibliotecas, escolas e filarmônicas, adquiriram recursos financeiros para manter seu aparato institucional por meio de financiamento do executivo e legislativo municipal e estadual. Exemplo disso foi o Grêmio Lítero-Beneficente Caixeiral de Itabuna, que em campanha para a construção do seu prédio próprio, recebeu da Intendência Municipal 1:000\$000 (Hum conto de réis), além da contribuição dos coronéis Martinho Conceição (banqueiro e comerciante), Nicodemos Barreto (banqueiro, comerciante e agricultor) e Godofredo Almeida do Espírito Santos (agricultor), todos com a quantia de $500 \$ 000$ (quinhentos mil réis) ${ }^{14}$.

Em Ilhéus, a Sociedade União Protetora dos Artistas e Operários recorreu ao Conselho Municipal ilheense para obter uma subvenção que deveria ser aplicada no funcionamento de sua escola noturna. Na mesma sessão, também a colônia de pescadores Z10 solicitava um auxílio financeiro aos conselheiros locais para a construção de sua sede no bairro do Pontal15. 0 reconhecimento do papel destas organizações trabalhistas pelos intendentes e parlamentares da região oferece a sensação de que os trabalhadores poderiam recorrer ao jogo democrático liberal da Primeira República quando fosse necessário, e pressionar intendentes, conselheiros e deputados por amparo político dos poderes públicos. Na conformação do projeto eleitoral das classes dominantes do sul da Bahia, responder às demandas das sociedades trabalhistas se tornou crucial para construir prestígio político junto às camadas populares.

Ao se aproximar das organizações representativas da classe trabalhadora regional e, sobretudo, ao garantir os auxílios financeiros provenientes do Estado, intendentes e deputados conseguiam promover suas carreiras políticas. Isso se reforçava na medida em que as agremiações de artistas e operários, movidas pelo interesse de se mostrarem gratas pelas concessões financeiras, agraciavam figuras políticas tradicionais com títulos de sócios beneméritos ou benfeitores. A Sociedade Monte Pio dos Artistas de Itabuna, reunida em assembleia geral no dia 9 de setembro de 1923, prestou uma homenagem ao deputado Gileno Amado, concedendo o título de sócio benemérito e colocando seu retrato na sede social ${ }^{16}$. A homenagem rendida ao parlamentar ocorreu três meses após ter solicitado uma subvenção de 5:000\$000 (cinco contos de réis) para aquela entidade na câmara federal no Rio de Janeiro17. Outro que também foi beneficiado com o título de sócio benemérito da mesma entidade de artistas foi o intendente cel. José Kruschewsky. Em 28 de agosto de 1923, a diretoria deliberou a

\footnotetext{
${ }^{14}$ CEDOC/UESC. Jornal de Itabuna, 13/3/1924, Ano IV, n.195. p. 2.

15 APMIJM. Jornal Correio de Ilhéus, 29/9/1923, ano III, n.381. p. 2.

${ }^{16}$ ASMPAI. Livro de atas da Assembleia Geral da SMPAI. Ata da 35a reunião ordinária. 9/9/1923. pp. 36v-37.

17 CEDOC/UESC. Jornal de Itabuna, 24/8/1922, Ano III, n. 113.
} 
entrega do certificado de sócio benemérito para o coronel, além da colocação de seu retrato na galeria da sede social18. Ao justificar tal medida, os membros do Monte Pio destacaram sua contribuição para a sobrevivência daquela sociedade de $\operatorname{artistas}^{19}$.

Estas movimentações de políticos e de organizações de trabalhadores durante a década de 1920 registram a forma com que se processavam as representações de classe na estrutura política da década final da Primeira República. Para as organizações de trabalhadores do sul da Bahia, o referido intervalo temporal era marcado por um momento de constituição de uma experiência associativa. Antônio Guerreiro de Freitas sinaliza que os anos 20 foram o momento em que, no sul da Bahia, "trabalhadores urbanos e rurais conheceram uma certa experiência política, associativa, sindical"20. Assim, tais entidades surgiram sob a justificativa de promover a solidariedade de classe entre seus membros, na busca por melhores condições de vida, em que um dos métodos adotados era se fazer representar diante das autoridades no quadro político local.

Aproximar-se destas autoridades políticas foi uma tarefa importante na linha de intervenção dos trabalhadores na sociedade regional, cujo objetivo seria o reconhecimento por parte das classes dominantes políticas e econômicas locais destas novas organizações trabalhistas. Tratava-se de demarcar uma diferença social e cultural destes sujeitos organizados diante de outras camadas populares, as quais sofriam frequentemente com o preconceito e a perseguição dos poderes públicos ${ }^{21}$. Por isso, ao se organizarem em sociedade de representação da classe, os trabalhadores esperavam amenizar seus problemas sociais (educação, moradia, salário, férias, condições de trabalho, etc.), os quais assolavam diversas categorias da região, adotando uma estrutura organizativa pautada na negociação com a patronal e com as autoridades políticas, inclusive selecionando como valores éticos elementos típicos das elites oligárquicas, a exemplo do lema "Deus, Pátria e Trabalho", expresso nos símbolos da Sociedade Monte Pio dos Artistas de Itabuna e da União Protetora de llhéus ${ }^{22}$.

A vontade de demarcar uma diferenciação social dos outros grupos de trabalhadores e 0 desejo de reconhecimento por parte das autoridades políticas eram explicitados durante as comemorações dos dias festivos, tais como dia do Trabalho, Independência e aniversário de fundação das sociedades. No terceiro aniversário da Sociedade Monte Pio de Itabuna, o Jornal

\footnotetext{
18 CEDOC/UESC. Jornal A Época, 29/8/1923, Ano VI, n. 34. Jornal A Época, 5/9/1923, Ano VI, n. 35.

${ }_{19}$ ASMPAI. Livro de atas da Diretoria das SMPAI. Ata da $15^{a}$ sessão ordinária. 22/8/1923. pp. 17-18.

20 FREITAS, Antônio F. Guerreiro. Caminhos ao encontro do mundo. Antônio Fernando Guerreiro de Freitas e Maria Hilda Baqueiro Paraíso. Ilhéus, Ba: Editus, 2001. p. 166.

21 BATALHA, Claúdio H. M. "Identidade da classe operária no Brasil (1890-1920): Atipicidade ou legitimidade?" In. Revista Brasileira de História. São Paulo, V.12, n. ${ }^{0} 23 / 24$, set.91/ago92.

22 ASMPAI. Estatutos da Sociedade Monte Pio dos Artistas de Itabuna. APMIJM.
} 
de Itabuna, periódico vinculado ao partido da Concentração Republicana, publicava um relato de autor anônimo que descrevia a comemoração dos artistas e frisava a falta de comparecimento de alguns representantes políticos. Dizia que notara "logo a falta naquele recinto do Governador do município ou de um representante, a falta dos srs. Drs. Juízes da comarca e do Dr. Promotor Público, de instituições e até de imprensa!". Para complementar a sua crítica, a carta destacava a importância daquela sociedade de artistas, afirmando que uma "instituição como é o 'Monte Pio', que honra sobremodo Itabuna, elevando seu nome, educando dezenas de seus filhos e valorizando uma classe grandiosa e honrada como é a dos artistas, creio que merecia um pouco mais de atenção dos poderes constituídos de Itabuna"23.

A legitimidade exigida pelas sociedades laborais frente aos poderes públicos perpassava pela expressão de uma consciência de classe que colocava os trabalhadores como sujeitos que operavam no engrandecimento das cidades com espírito cívico, ordeiro e patriótico. Desta forma, eles procuravam ser identificados por suas contribuições na construção do progresso da classe e da Pátria, sobremaneira, imbuídos por uma visão positivista de que era possível reformar a sociedade cobrando dos políticos melhorias e conquistas mínimas. Dentro deste quadro, citamos a carta enviada ao intendente Cel. José Kruschewsky sobre a comemoração do dia do Trabalho do ano de 1923. Os membros da Assembleia Geral do Monte Pio dos Artistas declararam o desrespeito do coronel intendente frente a "data sagrada" do $1^{\circ}$ de Maio, "dia este que foi consagrado ao trabalho do operariado pelo presidente da República". De acordo com ofício de resposta da intendência, foi solicitado ao Conselho Municipal que verificasse os motivos pelos quais não fora instituído o feriado do trabalhador em Itabuna ${ }^{24}$.

É importante frisar a posição dos trabalhadores da região em exigir dos poderes públicos municipais o fechamento do comércio e das repartições públicas. Em Ilhéus, a Sociedade União Protetora dos Artistas e Operários de llhéus e a Euterpe 3 de Maio conseguiram fazer cumprir junto a intendência a aplicação da lei que instituía o feriado do trabalho no país. Sobre isso, 0 Correio de Ilhéus, periódico do (PRD ilheense) e chefiado pelo cel. Antônio Pessoa, destacava que não deveria passar despercebida tal data, a qual marcaria "a glorificação do trabalho" e que tal comemoração representava uma "época de harmonia e progresso, e, desperta entusiasmos em nossos corações"25. Diante de tal consideração, podemos imaginar que mesmo assentados nos cargos de poder, os coronéis da região se sentiam forçados a reconhecer a data dos trabalhadores como expressão da força de uma cultura associativa operária, tanto de forma

\footnotetext{
${ }^{23}$ CEDOC/UESC. Jornal de Itabuna, 5/11/1922, ano III, s/d.

${ }^{24}$ ASMPAI. Livro de atas da Assembleia Geral da SMPAI. Ata da $41^{\text {a }}$ sessão ordinária. 6/5/1923. p. 48.

${ }^{25}$ APMIJM. Jornal Correio de Ilhéus, 1\%/5/1923, Ano III, n. 287. p. 1.
} 
voluntária, haja vista o caso de llhéus, como de modo compulsório com a pressão das sociedades de classes, a exemplo de Itabuna26. Daí, talvez, a busca pelos valores de "harmonia e progresso" da classe política na mediação com os trabalhadores. Por outro lado, ao incorporar à sua identidade a defesa do engrandecimento da Pátria por meio de uma ética do trabalho positiva, as agremiações operárias se distinguiam do restante do povo.

Para entender melhor esta posição das sociedades trabalhistas de Itabuna e llhéus em reafirmar valores cívicos e ordeiros na sua identidade de classe, basta notar que a política da Primeira República (alimentada pelos sentimentos de ordem e de progresso) não toleravam práticas de desordem urbana, familiar e cívica. As pesquisas em jornais apontam uma série de estigmas e perseguições impostos a costumes populares que fugiam à regra da cultura dominante. Em Itabuna, a imprensa registrou várias críticas a setores profissionais nãoorganizados e camadas empobrecidas da cidade. Em 30 de março de 1922, o Jornal de Itabuna denunciava a "promiscuidade de aguadeiros, animais de tudo quanto há porcaria naquele trecho [do rio Cachoeira], sem higiene e sem limpeza"27. Os aguadeiros eram trabalhadores de ganho que cobravam pelo serviço de distribuição de água pela cidade, cujas atividades eram frequentemente fiscalizadas pelas autoridades municipais. Outro periódico que também não se furtava de fazer suas acusações era o jornal $A$ Época, que em 1928, afirmava que "a vagabundagem é que deve pagar o tributo de sua improdutividade parasitária" 28 servindo voluntariamente aos trabalhos do cemitério municipal. Tal consideração também estava presente em llhéus, onde um dos principais periódicos destacava que

\footnotetext{
"nas esquinas, nos cantos de ruas, na praia, deparam-se constantemente, grupos e grupos de desocupados e capadócios [...] verdadeiros perigos para 0 pudor das famílias e para o respeito devido às pessoas conceituadas [...] Que a polícia então tome conta dessa malandragem desenfreada e torpe"29.
}

Diante das acusações e das repressões que a imprensa das elites políticas produzia em suas páginas, é possível compreender o porquê da conveniência de se diferenciar do restante do povo e aderir aos valores republicanos do sul da Bahia. A cultura associativa praticada pelos trabalhadores da região nos grêmios aqui identificados durante a década de 1920 quase sempre

\footnotetext{
${ }^{26}$ BATALHA, Claudio H. M. "Cultura associativa no Rio de Janeiro". In. Culturas de classe: Identidade e diversidade na formação do operariado. In: Claudio H. M. Batalha, Fernando Teixeira da Silva, Alexandre Fortes (orgs.). Campinas, SP: Ed. da UNICAMP, 2004. Batalha compreende como cultura associativa "o conjunto de propostas e práticas culturais das organizações operárias, a visão de mundo expressa nos discursos, bem como os rituais que regem a vida das associações que muitas vezes são herdados de formas de organização mais antigas, como as corporações". p. 99.

27 CEDOC/UESC. Jornal de Itabuna, 30/3/1922, Ano II, n.92. p. 1.

28 CEDOC/UESC. Jornal $A$ Época, 23/6/1928, Ano XI, n.419. p. 1

${ }^{29}$ APMIJM. Correio de Ilhéus, 28/10/1926, ano VI, n.812. p. 2.
} 
se identificava com os valores de Pátria, de trabalho e de religiosidade cristalizados durante 0 período republicano, sobretudo, na intenção de se legitimar frente à sociedade. Desta forma, ao reafirmarem seus compromissos morais e éticos com o projeto republicano e atuando dentro dos limites da legalidade, provavelmente os membros das agremiações trabalhistas se sentiam à vontade para reivindicarem suas demandas sociais e se inserirem nas articulações políticas locais. Acreditamos que pode valer para os trabalhadores organizados de llhéus e Itabuna o que Popinigis avaliou para os caixeiros cariocas, quando afirmou que eles souberam cobrar do Estado republicano o seu quinhão do projeto de cidadania fundado no progresso e no enaltecimento da Pátria ${ }^{30}$.

A compreensão da forma como os trabalhadores vivenciavam as regras sociais e culturais do jogo político, é vital para localizar o papel desempenhado pelas organizações trabalhistas na relação com as autoridades do sul da Bahia. Entendemos que é viável observar que mesmo diante de práticas coronelísticas autoritárias e excludentes, "os de baixo" não ficavam passivos e tinham sua parcela de atuação frente à classe política. Um episódio em que se processou esta condição foi durante as reuniões promovidas pela Intendência Municipal para debater a questão da carestia de preços em Itabuna. Naquele encontro, estavam presentes várias entidades de classe patronal e trabalhista, dentre as quais, a Sociedade Monte Pio de Itabuna, representada pelos seus sócios Júlio Ferreira dos Santos, Ismael Casais, Manoel Vidal e Flaviano Moreira. Nas discussões, fez uma intervenção o sr. Flaviano Moreira, propondo que o poder público municipal exigisse do governador Góes Calmon, por intermédio do líder parlamentar Gileno Amado, que o estado adquirisse produtos de primeira necessidade junto ao centros produtores e que aplicasse isenção de impostos paras empresas que fizessem 0 transporte para a região sul da Bahia, contribuindo assim para a diminuição dos preços dos produtos em Itabuna ${ }^{31}$. Independente da proposta apresentada, este episódio vale mais pela iniciativa do intendente coronel em discutir uma questão social, lançando mão de um debate com representantes da classe trabalhadora e, por outro lado, da capacidade que estes possuíam de participar ativamente junto às outras associações políticas e patronais presentes nesta comissão local32.

\footnotetext{
30 POPINIGIS, Fabiane. Proletários de casaca: trabalhadores do comércio carioca, 1850-1911. Campinas, SP: Editora da UNICAMP, 2007. A autora destaca a compreensão dos empregados no comércio sobre os valores de "progresso" e de "civilização" elaborados pelo projeto republicano. Ela defende que se apropriando destes ideais e atuando nos limites da legalidade, os comerciários conseguiram cobrar da República questões relacionadas à uma legislação social de proteção aos trabalhadores. p. 28.

31 IGHB. Jornal O dia, 19/7/1924, ano V, n. 264.

32 As informações sobre esta comissão também pode ser encontrada em CEDOC/UESC. Jornal de Itabuna, 24/7/1924, ano V, n. 214. p. 1.
} 
Em dezembro de 1923, o cel. José Kruschewsky finalizou sua gestão na Intendência Municipal, sendo substituído por outro coronel, Laudelino Lórens, o qual ainda mantinha 0 bastião do PRD de Gileno Amado e de J. J. Seabra erguido em Itabuna, mesmo com os graves sintomas de crise apresentados pelo Seabrismo na Bahia33. Durante este período, o cel. Kruschewsky que havia sido eleito em um pleito marcado pela abstenção dos eleitores, aceitou a proximidade das organizações operárias, garantindo subvenções e convidando-as para iniciativas de caráter político e social das municipalidades. Com estas ações, ele sabia que não podia fazer política e governar a cidade sem obter prestígio, ainda que básico, junto às entidades de representação da classe trabalhadora regional. Mais além de Kruschewsky e Amado, outros políticos também sabiam que não era possível fazer disputa eleitoral sem apoio dos "de baixo", entre eles o líder de oposição ao seabrismo no sul da Bahia, o bacharel João Mangabeira.

\section{Trabalhadores, organizações e disputas eleitorais}

Como dissemos anteriormente, a década de 1920 foi marcada por mudanças no quadro político estadual que terminaram influenciando as relações que as agremiações operárias estabeleceram com intendentes, deputados e governadores. Até 1923, as autoridades políticas sul baianas estiveram sintonizadas na órbita do Seabrismo ${ }^{34}$. A partir daquele ano, os seabristas começaram a dar sinais de desorganização no estado. Em Itabuna, a repercussão imediata foi a polarização das disputas políticas em torno dos deputados federais Gileno Amado e João Mangabeira. Já vimos que Amado frequentava o interior das entidades dos trabalhadores, tendo sido homenageado como sócio benemérito por algumas associações. No entanto, ele não era 0 único. Conforme avançava a década de 1920, a presença de João Mangabeira se fez mais significativa nas sedes sociais dos grêmios operários. Em llhéus, a principal liderança, Antônio Pessoa, que há mais de dez anos estava ao lado de J. J. Seabra, rompeu com o chefe do PRD e se inscreveu nas linhas da Concentração Republicana, partido que apoiou a candidatura de Góes Calmon ao governo da Bahia em 1924. Para tanto, Pessoa havia optado por se unir a João Mangabeira que outrora tinha sido um de seus adversários históricos na política sul baiana da

\footnotetext{
33 Apesar de eleito pela segunda vez para governador da Bahia, a gestão de Seabra entre os anos de 1920 e 1924 foi marcada por um enfraquecimento progressivo do seu poder de influência sobre as facções partidárias do sul do estado. Em Itabuna, Gileno Amado preservou a força do Seabrismo, dando apoio à intendência de José Kruschewsky e de Laudelino Lórens entre 1920 e 1925. Daí em diante, veremos que a subida de Góes Calmon é acompanhada pelo fortalecimento de João Mangabeira no eixo Ilhéus-Itabuna. SAMPAIO, Consuelo Novais. Partidos políticos da Bahia na Primeira República: uma política de acomodação. Salvador: Ed. da Universidade Federal da Bahia, 1998. pp. 159-167.

34 Denominação dada ao grupo político liderado por J.J. Seabra a partir de 1912, quando assumiu a hegemonia política da Bahia, e que se manteve forte até 1924, momento em que perdeu espaço para Góes Calmon, governador do estado em 1925.
} 
década de 191035. Por isso, a atuação de João Mangabeira nos círculos operários ilheenses passou a ser mais corrente, principalmente com o aparecimento de associações de caráter mutualista e recreativo no decorrer dos anos 20.

Esse contexto de enfraquecimento do Seabrismo na Bahia e sua repercussão no sul do estado se tornou mais evidente nas eleições parlamentares que aconteceram entre os anos de 1921 e 1925. Para obter mais prestígio e votos junto à população, a oposição à J. J. Seabra buscou criar e reforçar seus vínculos junto às entidades trabalhistas regionais. Em Itabuna, João Mangabeira iniciou a construção de seus vínculos desde 1921, quando foi homenageado pela Sociedade Monte Pio de Itabuna. Aliás, em torno deste ato, houve várias desavenças entre os membros daquela associação, visto que os estatutos da entidade proibiam a veiculação de quaisquer propagandas políticas no interior da organização.

A aproximação entre o Monte Pio e João Mangabeira começou em 14 de novembro de 1920, quando reunidos em assembleia geral, os associados Flaviano Moreira, Luiz da França e Júlio Santos propuseram que o deputado federal fosse beneficiado com o primeiro título de sócio benemérito daquela entidade. Como justificativa, os proponentes afirmaram que :

\begin{abstract}
"reconhecendo os grandes serviços prestados à causa desta sociedade pelo ilustre parlamentar, Dr. João Mangabeira, serviços estes como o das subvenções obtidas pelo ilustre senhor nas casas altas do país, e passada em $3^{\text {a }}$ discussão, em benefício de nossa instituição, Monte Pio dos Artistas, pela presente recompensa aos seus ditos esforços oriundos do seu espírito de trabalhador incansável pela causa do bem como é a nossa causa, sem com isto termos intentos políticos ou desejos de a tal nos congregarmos, propomos como nos é lícito, que esta assembleia confira ao mesmo Dr. João Mangabeira o título de sócio benemérito desta casa, colocando na galeria de honra desta casa o seu retrato, como reconhecimento aos seus nunca esquecidos esforços." 36
\end{abstract}

A proposta foi aprovada por unanimidade naquela assembleia, tendo ficado acertado que o seu retrato fosse colocado na futura sede social que estava a ser construída.

Apesar da aceitação imediata dos membros do Monte Pio da proposta de título benemérito ao deputado federal naquela reunião, a deliberação tomada foi alvo de questionamentos por outros sócios. Em janeiro de 1921, Flaviano Moreira, presidente da Assembleia Geral, recebeu um boletim político anônimo que procurava saber "qual a atitude do

\footnotetext{
${ }^{35}$ Sobre informações para o quadro político estadual, ver SAMPAIO, Consuelo N. Op. Cit.; NORONHA, Sílvia Sarmento. A raposa e a águia: J.J. Seabra e Rui Barbosa na política baiana da Primeira República. Dissertação de Mestrado. Salvador: PPGH/UFBA, 2009. Em relação às questões partidárias da região sul da Bahia, consultar FALCON, Gustavo. Os coronéis do cacau. Salvador: lanamá/Ed. UFBA, 1995.

${ }^{36}$ ASMPAl. $1^{\circ}$ Volume do livro de atas da Assembléia Geral da S.M.P.A.I. Ata da $15^{\circ}$ sessão da Assembleia Geral. 14/11/1920, ff. 36-37.
} 
Monte Pio em face da candidatura do Dr. João Mangabeira?"37. O boletim gerou uma discussão acalorada entre os associados, tendo Moreira reconhecido as restrições que os estatutos impunham quanto às atividades político-partidárias. 0 regimento da entidade era claro no combate aos sócios que se manifestassem por partidos ou grupos políticos, tendo em vista a preocupação com a autonomia da sociedade frente às eleições. Sem dúvida, o mal-estar por homenagear um candidato político no interior deve ter pairado no ar.

No entanto, a contenda não parece ter sido solucionada por aí. Outra sessão da assembleia geral foi convocada por vários membros, cujo objetivo seria tomar decisões sobre a vinda do deputado Mangabeira para Itabuna. Logo após o início do expediente, o sócio Luiz da França pediu a palavra e "disse que admirava o Sr. Presidente [Flaviano Moreira] ter sido o iniciador do Monte Pio, autor dos estatutos do mesmo, portanto conhecedor das leis sociais, e estar agindo politicamente com o nome do Monte Pio", informando ainda que na lista de sócios que convocava a presente reunião "eram todos Mangabeiristas". Em resposta, o presidente da entidade, auxiliados pelos consócios Virgílio Theotônio e Genésio Vitoriano, dizia que "eram injustas as acusações, pois estavam agindo em favor de um sócio benemérito e não de um político"38. Muito provavelmente, alguns sócios que se arregimentavam em torno do grupo de Gileno Amado não ficaram satisfeitos com a presença de Mangabeira entre os membros da sociedade.

Mesmo sob a desconfiança de alguns de seus pares, a direção da Sociedade Monte Pio de Itabuna decidiu preservar a proposta de concessão do título benemérito a João Mangabeira. Não apenas isso, eles aproveitaram também a oportunidade em que o deputado federal estava na cidade para programar uma solenidade em sua homenagem. Na organização, ficou acertado que os associados da entidade se reuniriam em frente à gare da Estrada de Ferro para conduzir Mangabeira até a residência em que ficaria hospedado, provavelmente no casarão do cel. Henrique Alves. O convite ao político foi feito por meio de telegrama, em que destacava o crédito de "alta simpatia [da] coletividade engrandecida [por] seus esforços como representante [da] Alta Câmara País onde se impôs como incansável trabalhador em prol das nossas instituições [e] classes [e] vosso berço natal." 39

Ainda que diante de impedimentos legais da entidade, a Sociedade Monte Pio se esforçou para se aproximar das autoridades políticas mais expressivas da região. Aliás, na

\footnotetext{
${ }^{37}$ ASMAPI. $1^{\circ}$ Volume do livro de atas da Assembléia Geral da S.M.P.A.I. Ata da $16^{\text {a }}$ sessão da Assembleia geral. $21 / 1 / 1921$, ff. $39 \mathrm{v}-40$.

${ }^{38}$ ASMAPI. $1^{0}$ Volume do livro de atas da Assembléia Geral da S.M.P.A.I. Ata da $17^{\text {a }}$ sessão da Assembleia geral. 5/2/1921, ff. 42-42v.

39 Idem, ibidem.
} 
proposta da solenidade para João Mangabeira, o presidente Flaviano Moreira sugeriu convidar também Gileno Amado para presidir a mesa da assembleia especial. Nesta oportunidade, provavelmente os dirigentes do Monte Pio queriam agradar a dois senhores, visto que naquela oportunidade ambos os políticos reivindicavam a autoria do projeto de lei que garantia subvenções federais para a entidade. Ou talvez, a tentativa de amenizar as suspeitas de alguns consócios sobre as homenagens a Mangabeira, conforme citamos anteriormente. No entanto, unir os dois adversários políticos na mesma festa não foi possível. Contudo, aquela homenagem parecia ser uma encenação de deferência em relação às autoridades, pois o objetivo era claramente juntar-se aos políticos locais para obter vantagens financeiras e reconhecimento junto à sociedade política.

O desfecho das discussões em torno da vinda de João Mangabeira ao Monte Pio ocorreu em 12 de fevereiro de 1921, quando reunidos numa assembleia geral, os associados promoveram a homenagem ao parlamentar federal. Junto com o presidente Flaviano Moreira e 0 diretor Manoel Vidal, formou-se uma comissão com autoridades políticas de Itabuna, entre elas, os coronéis Ruffo Galvão, Antônio Rodrigues Portella, Gerosyno Almeida (todos eles vinculados mais tarde à Concentração Republicana), para buscarem o deputado benemérito na residência do chefe local, coronel Henrique Alves dos Reis. Foi sob a presidência deste último que a sessão magna foi dirigida e após longo discurso do orador da agremiação Manoel Vidal, em que ressaltou as qualidades e as ações de Mangabeira na política do país, inaugurou-se o seu retrato e Ihe foi entregue o título de primeiro sócio benemérito da Sociedade Monte Pio dos Artistas de Itabuna ${ }^{40}$. Em resposta às homenagens recebidas, os artistas registraram em ata que Mangabeira afirmou:

\begin{abstract}
"Que deixava bem patente o seu amor aos operários e artistas de Itabuna, versou sobre o nosso célebre escudo Trabalho, Força e União, e perorou animado os artistas de Itabuna a se unirem porque da união é que vem a energia para que não se deixassem explorar, e que [...] estaria ao lado dos mesmos em qualquer que fosse a circunstância, pois conservava na memória para sempre que foi as homenagens recebidas pelo Monte Pio dos Artistas e, terminou prometendo, que depois das eleições antes que sua Ex $x^{a}$ viajasse para a capital do país, viria em Itabuna para combinar a organização de uma oficina para diversas artes, e prometendo que no orçamento vindouro da República incluiria uma subvenção de 15 ou vinte contos para a manutenção desta oficina e também para a obtenção de aparelhos e maquinismos;"41
\end{abstract}

\footnotetext{
${ }^{40}$ ASMAPI. $1^{\circ}$ Volume do livro de atas da Assembléia Geral da S.M.P.A.I. Ata da $17^{\text {a }}$ sessão da Assembleia geral. 12/2/1921, ff. 44-45v.

41 Idem, ibidem, ff. 44v-45.
} 
Seria supérfluo dizer que, ao ouvir a promessa de Mangabeira, os dirigentes e os associados do Monte Pio dos Artistas tenham se agradado com as palavras do deputado. Para eles, receber os recursos do governo federal era o sinal de que apesar de ter pouco mais de um ano, possuíam a capacidade de obter reconhecimento suficiente para barganhar vantagens junto às autoridades políticas locais. Mais a questão primordial é perceber que aquele jogo de interesses políticos trocados entre as agremiações trabalhistas e João Mangabeira se processavam em meio a uma disputa eleitoral. Não foi à toa que o novo sócio benemérito dos artistas prometia retribuir ao seu público com uma subvenção federal de mais de 15:000\$000 (quinze contos de réis), quando em média o poder municipal pagava 1:000\$000 (hum conto de réis), apenas. Oito dias depois de realizada aquela solenidade ocorreriam as eleições para representante parlamentar da Bahia, em que figuravam como candidatos adversários do sul do estado Gileno Amado (PRD) e João Mangabeira (PRB). Não por acaso, o jornal $A$ Época, denunciava o esforço de seu adversário político em captar votos nos dias que antecederam 0 pleito. Dizia o periódico que:

\footnotetext{
"A cabala esteve intensíssima em favor do Dr. João Mangabeira por parte da Associação Comercial e da Sociedade Monte Pio dos Artistas e dos poucos políticos da facção de Henrique Alves, os quais usaram de todos os meios, esbanjando dinheiro e promessas, para evitar maior derrota do seu candidato [...] A propaganda chegou ao extremo e o próprio sr. Mangabeira foi pessoalmente, de porta em porta, cavar seus votinhos, canseira a que nunca se abalara nos gordos tempos de outrora." 42
}

Apesar de ter percorrido as principais associações de classe do município, em especial a dos artistas, as informações encontradas sugerem que mesmo com boa votação, Mangabeira não foi o candidato mais votado em Itabuna. Contudo, se deixamos de lado o resultado das eleições e refletirmos sobre os métodos eleitorais dos políticos da região sul da Bahia, veremos que obter prestígios juntos às agremiações operárias era um passo fundamental para conseguir êxito nas disputas políticas locais. Isso nos faz pensar que as lutas eleitorais não se processavam apenas a partir do voto de cabresto ou da violência sobre os eleitores, mas que também havia espaço para catalisação de apoio nos organismos da classe trabalhadora urbana. Obviamente, os representantes dos trabalhadores cobravam por isso, exigindo dos candidatos vantagens oficiais (subvenções) e não-oficiais (doações particulares) para suas agremiações. Se considerarmos este comportamento, podemos imaginar que nas relações paternalistas entre os dominados e dominantes, havia a construção de uma deferência social dos artistas e operários

\footnotetext{
${ }^{42}$ CEDOC/UESC. Jornal A Época, 26/2/1921, ano IV, n. 25. p. 1.
} 
para com suas autoridades, tal como Thompson ${ }^{43}$ afirmava, e que isto fazia parte de uma tática em que os mais "fracos" consumiam dissimuladamente as relações políticas regionais com 0 objetivo de obter benefícios que ajudavam a preservar a sobrevivência de uma cultura associativa proletária (grêmios, filarmônicas, escolas, clubes, etc. ${ }^{44}$. 0 consumo subalterno desta rede política não implicava em grandes alterações sociais e muito menos em ato de rebeldia, mas possibilitava que neste jogo de barganha com as elites políticas, os trabalhadores organizados alcançassem à base de um reformismo e de uma docilidade, certas pautas sociais de proteção e de ampliação do aparato institucional operário no sul da Bahia.

Nas redes do poder do Coronelismo no sul da Bahia havia espaço para as articulações políticas que envolviam os trabalhadores e suas organizações. Com efeito, isso nos faz pensar que a questão social na Primeira República extrapolou as práticas autoritárias das elites políticas ${ }^{45}$, sendo possível enxergar a forma com que os "de baixo" colocavam seus interesses diante das disputas entre as oligarquias regionais pela hegemonia. O que proponho, portanto, é que se os representantes das oligarquias regionais sabiam utilizar a democracia liberal e excludente da Primeira República para defender seus projetos políticos hegemônicos, os trabalhadores não estavam alheios. Eles aproveitavam as brechas do processo eleitoral para encaminhar suas demandas em troca de vantagens em curto prazo. Sem dúvida, o prestígio junto às bases eleitorais dos grêmios trabalhistas era fundamental para projetar as candidaturas, mas não sem antes garantir subvenções para estas entidades. Doravante, se compreendermos que escolas e filarmônicas das associações operárias eram mantidas por estes recursos públicos, podemos dizer que indiretamente os trabalhadores pretendiam alcançar direitos à educação e ao lazer que inexistia para maior parte da sociedade ${ }^{46}$.

Em outras eleições, Mangabeira fez questão de evidenciar sua inserção nas redes organizacionais dos trabalhadores de Itabuna e de llhéus. Na oportunidade, o periódico A Época

\footnotetext{
43 THOMPSON, E. P. Costumes em comum: estudos sobre a cultura popular tradicional. Revisão técnica Antônio Negro, Cristina Meneguelo, Paulo Fontes. - São Paulo: Companhia das Letras, 1998. p. 78.

44 CERTEAU, Michel de. A invenção do cotidiano 1: Artes de fazer. Petrópolis, RJ: Vozes, 1994. Utilizo aqui a compreensão de que o consumo dos "fracos", conforme se refere Certeau, ocorre quando os subalternos conseguem subverter de dentro da ordem da força ou da sedução impostos pelos "fortes", representações e práticas de dominação em seu favor. Ver capítulo III, Fazer com: usos e táticas, p. 89.

${ }^{45} \mathrm{FRENCH}$, John D. "Proclamando leis, metendo o pau e lutando por direitos". In. Direitos e justiças no Brasil. Sílvia Hunold Lara e Joseli Maria N. Mendonça. Campinas, SP: Ed. da UNICAMP, 2006. Tenho procurado me orientar no que propõe John French, quando afirma que a questão social na Primeira República não foi exclusivamente um caso de polícia, como quis transparecer a propaganda getulista, levando em consideração que a relação entre trabalhadores e Estado na década de 1920 implicou também em luta e conquista de direitos para "os de baixo". pp. 382-392.

46 GOMES, Angela C. Cidadania e direitos do trabalho. Rio de Janeiro: Jorde Zahar Editor, 2002. A autora afirma que "falar de uma história dos direitos do trabalho no Brasil é falar também de uma história das formas de organização dos trabalhadores. [...] as organizações de matriz corporativa, clássicas do mundo do trabalho, chamem-se ligas, clubes, centros, resistências, associações mutualistas ou sindicatos". p. 17.
} 
afirmava que João Mangabeira desprezava os votos do município de Itabuna. Como resposta, o Jornal de Itabuna respondia que a forma de mostrar como aquele último prezava os votos itabunenses era apresentar os "valiosíssimos serviços que saltam aos olhos, como a subvenção à Sociedade Monte Pio dos Artistas de Itabuna, Hospital da Misericórdia, Associação dos empregados de llhéus, a remodelação completa de llhéus, e grandes outros benefícios feitos ao sul da Bahia"47. Vale lembrar que todo esse clima de disputa se deu em 1923, quando por conta do enfraquecimento da liderança de J. J. Seabra, João Mangabeira se aliou com Antônio Pessoa em torno do partido da Concentração Republicana, e Gileno Amado sofria as primeiras perdas na política do sul da Bahia48.

Para reafirmar sua candidatura para deputado federal no pleito de fevereiro de 1924 , Mangabeira publicou na imprensa itabunense a seguinte pergunta: "Às classes conservadoras e ao operariado, porque Itabuna não há de eleger o DR. JOÃO MANGABEIRA, o invicto defensor das suas classes laboriosas, cuja efígie, como gratidão aos seus inigualáveis serviços, honra as galerias da Associação Comercial e do Monte Pio dos Artistas?"49. Ao resgatar sua projeção nas principais associações, em especial a dos trabalhadores, o candidato procurava reforças a legitimidade de sua campanha e obter os votos necessários pra sua eleição.

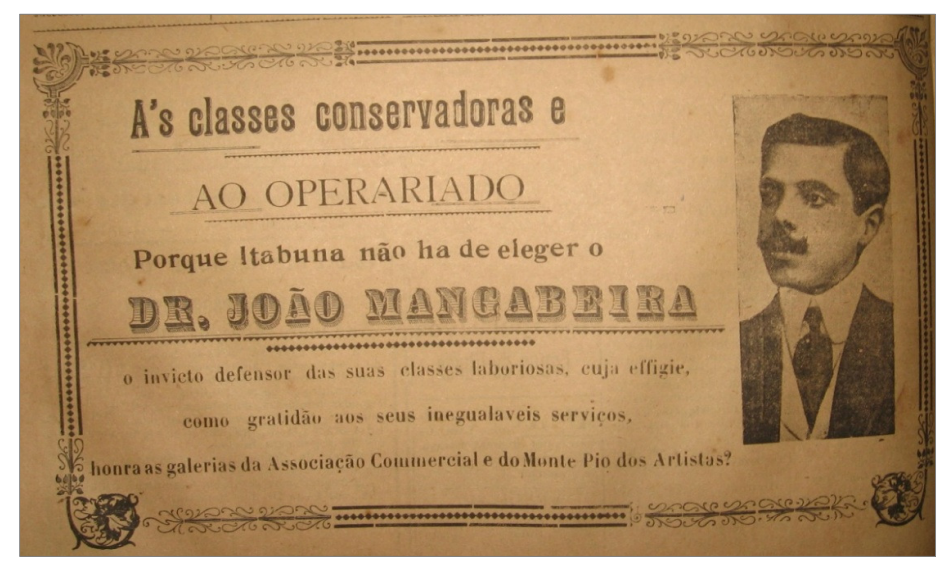

Figura 2- Propaganda eleitoral de João Mangabeira à eleição de 17/2/1924. Jornal de Itabuna, 14/2/1924, ano IV, n. 191. p. 4.

O que acontecia em Itabuna ocorria também em Ilhéus. Aliás, muito comum era que os deputados federais retornassem até a região para fazer campanhas ou referendar sua condição de benemérito nas sociedades de classe dos municípios. Em 1925, a Associação dos Empregados no Comércio de llhéus elaborou uma sessão solene para homenagear o deputado João Mangabeira. Na oportunidade, Edylio Ribeiro, representante dos comerciários, destacava o

\footnotetext{
${ }^{47}$ CEDOC/UESC. Jornal de Itabuna, 29/11/1923, Ano IV, n.180. p. 1.

${ }^{48}$ FALCON, Gustavo. Os coronéis do cacau. Op. Cit.

${ }^{49}$ CEDOC/UESC. Jornal de Itabuna, 14/2/1924, Ano IV, n. 191. p. 4.
} 
empenho do parlamentar na câmara federal pelo progresso da sua agremiação. Em resposta, 0 homenageado se dizia "bem impressionado com o desenvolvimento da Associação em tão pouco tempo" e reafirmou seu compromisso com os trabalhadores de llhéus ${ }^{50}$. Naquela altura, Mangabeira vivia seu momento de maior prestígio junto à sociedade ilheense na década de 1920, sobretudo por ter se tornado o líder do partido da Concentração Republicana no sul da Bahia. Em menos de uma semana, ele já tinha sido homenageado duas vezes por outras entidades filantrópicas, entre elas, o Colégio Nossa Senhora da Vitória, que também recebia benefícios do Estado. Como vimos, os empregados no comércio também não perderam sua chance de buscar agradar a sua autoridade política.

Todavia, não era apenas Mangabeira que se projetava naquela cidade. Também outro deputado federal, Ramiro Berbert de Castro, fundou vínculo com uma importante agremiação ilheense, a União Protetora dos Artistas e dos Operários de Ilhéus. Os membros do grêmio organizaram uma recepção para o parlamentar em sua residência, considerado por eles como "operoso conterrâneo", local em que falaria "aos operários de llhéus, de quem S. ex. é um grande amigo, discorrendo sobre assuntos sociais que interessam aquela classe"51. Nos registros da imprensa encontramos a realização da recepção a Berbert de Castro, que contou também com a presença de outras associações, dentre as quais, a Associação dos Empregados no Comércio de Ilhéus, Grêmio Olavo Bilac e Filarmônica 3 de maio. Em relação à União Protetora, o orador Camilo Lellis da Matta destacou os cumprimentos dos artistas ao deputado, provavelmente reafirmando a condição de "dedicado patrono no Parlamento da República" daquela entidade ${ }^{52}$. Meses depois, o Correio de Ilhéus informava que o deputado federal havia garantido subvenções para o ginásio Castro Alves, pertencente à União Protetora53.

Diante desta relação entre os artistas (a partir de suas organizações) e as autoridades políticas do sul da Bahia durante a década final da Primeira República, aparece-nos uma questão para refletir, qual seja, a de como se processavam os modos de dominação na prática do Coronelismo. Até aqui já vimos que havia uma atitude permissiva ante o desenvolvimento de uma cultura associativa entre os artistas e os comerciários da região por parte das elites. Antes, podemos dizer que havia uma relação de reciprocidade entre estas elites políticas e os trabalhadores organizados, cujas relações eram cautelosamente percebidas por ambas as partes. Se era mais fácil para os agentes políticos institucionais jogar jagunços e policiais contra os pobres "não-organizados" e miseráveis, acusando-os de malandragem, vadiagem e jogatina,

\footnotetext{
50 APMIJM. Correio de Ilhéus, 2/4/1925, ano V, n.577. p. 1.

${ }^{51}$ APMIJM. Correio de Ilhéus, 2/3/1926, ano V, n.717. p. 1.

52 APMIJM. Correio de Ilhéus, 6/3/1926, ano V, n.719. p. 1.

${ }^{53}$ APMIJM. Correio de Ilhéus, 3/7/1926, ano VI, n.767.p. 1.
} 
algo impedia de fazer o mesmo com os sujeitos que se abrigavam nas tendas do associativismo mutualista, ordeiro e pacífico. Por isso, foi necessário criar outros meios de exercício do domínio. Pensando que a década de 1920 foi um período marcado pela desarticulação do seabrismo na Bahia e pela articulação de novos grupos políticos - liderados pelos Calmom de Salvador lideranças que antes estavam na oposição, o preço que as oligarquias regionais em disputa precisaram pagar para obter a hegemonia política era cativar o máximo possível as organizações operárias por meio de reconhecimento social e de auxílios financeiros públicos. Com isso, deputados, intendentes e coronéis esperavam a gratidão e a garantia da ordem política por parte do proletariado respeitável.

Restava aos trabalhadores se aproveitar desta fragilidade do sistema político da Primeira República, consumindo as disputas oligárquicas ao conceder títulos beneméritos para autoridades partidárias de facções rivais e contar com a possibilidade de usufruir dos rápidos benefícios que poderia adquirir ${ }^{54}$. Numa sociedade marcada pela prática do clientelismo político, é preciso atentar para as formas que estes trabalhadores criaram para se apropriarem das regras do jogo eleitoral em benefício próprio. Bem mais do que sujeitos passivos nestas encruzilhadas eleitorais, poderemos notar a capacidade que "os de baixo" possuíam de avaliar, conforme seus interesses, os caminhos e descaminhos das disputas entre as oligarquias regionais ${ }^{55}$. Desta forma, construíam uma cultura associativa, criando escolas, filarmônicas, clubes recreativos, mas também, encontrando espaço para reivindicar direito à educação, ao lazer e à participação política. As elites políticas estavam atentas a este avanço de associações proletárias no sul da Bahia, inserindo-as na disputa eleitoral, cujo fim era se afirmar nas disputas oligárquicas pela hegemonia política ao fim da Primeira República. Enquanto isso, os empregados no comércio e operários construíam a imagem de si mesmos muito gradualmente, empregando boas relações com deputados, intendentes e coronéis para obter seu quinhão de cidadania.

\section{Coronelismo, trabalhadores e história social da política}

"o coronelismo ilheense evoluiu para duas vertentes políticas fundamentais que se enfrentavam com vistas à detenção do poder, excluindo nesse processo 0

\footnotetext{
${ }^{54}$ Cf. THOMPSON, E.P. As peculiaridades dos ingleses e outros artigos. Organizadores Antonio Luigi Negro e Sérgio Silva. Campinas, SP: Ed. da UNICAMP, 2001. Diz o autor que "A classe dominante encontrava uma legitimação, exercendo um poder 'constitucional' e dominando por intermédio de um processo verdadeiramente legal, as classes dominadas afirmavam a imagem de si mesmas como ingleses nascidos livres, com direito igual perante a lei" (p.224-5). No nosso caso em específico, defendo que os membros das agremiações laborais utilizavam das regras da política local conforme suas necessidades.

${ }^{55}$ NEGRO, Antônio Luigi. "Paternalismo, populismo e história social". In. Cadernos AEL, v.11, n.20-21, 2004. pp. 2930.
} 
conjunto da sociedade e relegando sobretudo a população trabalhadora das fazendas à condição de massa de manobra no jogo político municipal."56 (grifos meus)

"O que quer que tenha sido essa hegemonia, ela não envolvia a vida dos pobres, nem os impedia de defender seus próprios modos de trabalho e lazer e de formar seus próprios rituais, suas próprias satisfações e visão de mundo. Isso nos alerta contra levar a noção de hegemonia longe demais e a áreas inadequadas." 57 (grifos meus)

"De ordem do sr. Presidente da Associação dos E. no Comércio de llhéus, são convidados todos os consócios [...] para proceder-se a nova eleição e 0 cumprimento ao acordo havido com a intervenção do nosso mui benemérito sócio, Dr. João Mangabeira, que acha por bem fazer desaparecer qualquer ressentimento que possa existir às partes dos dois grupos que vem se mantendo em posições opostas - mesmo porque é único dever de todo consócio trabalhar em prol do engrandecimento desta útil Instituição."58 (grifos meus)

Os destaques feitos acima nos levam a refletir profundamente sobre o entendimento das práticas políticas no contexto de uma sociedade influenciada pelo coronelismo. Por um bom tempo, cristalizou-se na produção historiográfica do sul da Bahia a compreensão de que as relações de forças entre as diferentes classes sociais relegaram os trabalhadores pobres à posição de massas de manobras, vítimas do autoritarismo das oligarquias e incapaz de reivindicar seus interesses frente à classe dominante. Evidente que o coronelismo representou a hegemonia de oligarquias regionais que disputavam os cargos institucionais do Estado. Sobretudo, impôs o uso da violência quando as diferenças entre os diversos grupos políticos dominantes se acentuavam, ou então, quando os populares buscavam os caminhos de rebeldia para enfrentar o poder e defender suas práticas culturais. Sobre isso, não faltam análises históricas que se debruçaram arduamente no estudo destas práticas autoritárias. Mas, sobretudo, já advertia José Murilo de Carvalho para o fato de que as pesquisas sobre este período tinham um rendimento decrescente, visto que as ideias e os conceitos "giravam em roda" e retornavam ao mesmo lugar 59 .

No entanto, se buscamos outros entendimentos sobre a cultura política da Primeira República e queremos repensar o conceito de Coronelismo largamente utilizado pelos historiadores, devemos levar em consideração que as práticas hegemônicas deste período não se encerravam no exercício do poder autoritário e totalizador. Nem as elites políticas praticavam só a violência física e simbólica, nem muito menos os pobres artífices e operários se deixavam abater submissamente pelos "de cima". Parece válido que, mesmo diante dos coronéis e

${ }^{56}$ FALCON, Gustavo. Os coronéis do Cacau, Op. Cit., p. 117.

57 THOMPSON, E. P. Costumes em comum. Op. Cit. p. 78.

${ }^{58}$ APMIJM. Correio de llhéus, 13/3/1926, ano V, n.722. p.1.

${ }^{59}$ CARVALHO, José Murilo de. Pontos e bordados: escritos de história e política. Belo Horizonte: Ed. da UFMG, 2005. 
autoridades políticas, os trabalhadores artistas não se deixavam envolver absolutamente pelos mandos e desmandos, ao passo que erguiam uma cultura associativa que se traduzia numa tenda de proteção e garantia de seus modos de lazer, de trabalho e de representar seus interesses. Por isso, o conceito de Coronelismo torna-se valioso se, para além da expressão de poder autoritário de intendentes, deputados e governadores, não condicionarmos esta experiência política num presídio de segurança máxima em que o proletariado não tenha condições de existir ativamente. Antes, que este conceito seja entendido como uma disputa de força entre as classes sociais antagônicas, em que por vezes usavam da força para imprimir sua hegemonia, mas por vezes necessitam da habilidade para negociar com os trabalhadores, reconhecendo seus direitos de sociabilidade, de lazer, de educação e de trabalho.

A historiografia brasileira já deu mostra de que é possivel "resgatar da condescendência do passado" sujeitos sociais empobrecidos e subalternos, sinalizando as formas com que estes se apropriaram, resignificaram ou resistiram aos modos de dominação $0^{60}$. Tais posicionamentos nos levam a entender o significado do posicionamento das diversas entidades operárias no sul da Bahia. É possível afirmar, seguramente, que os trabalhadores arregimentados nestas associações tiravam proveito ao se apropriarem das disputas políticas das oligarquias regionais, cobrando seu preço para prestigiar as autoridades políticas. No entanto, vimos que mesmo assim, por vezes não conseguiam agradar a todos, gerando oposições internas nos grêmios trabalhistas, conforme notamos na fonte citada acima. Aliás, estudar esta complexa relação entre políticos e trabalhadores sinaliza o poder de mobilização destes últimos e como eles eram decisivos nas disputas eleitorais baianas, como trata Aldrin Castelucci em sua tese sobre 0 envolvimento do Centro Operário da Bahia com a máquina política da Primeira República61.

Portanto, na ambição de levar a cabo sua estratégia de hegemonia, os agentes políticos de práticas coronelistas no sul da Bahia precisaram reconhecer a representação dos trabalhadores, lançando mão de um tratamento das questões sociais diferente daquele oferecido ao restante da população pobre, que sofria com a perseguição policial. Em outros trabalhos, discuti como empregados das fazendas, feirantes, carregadores e outros ganhadores urbanos enfrentaram o mando de patrões e coronéis. Isso acontecia quando brigavam pelo pagamento de suas diárias em trabalhos realizados nas cidades ou quando encaravam as ações das

\footnotetext{
60 CHALHOUB, Sidney; DA SILVA, Fernando Teixeira. "Sujeitos no imaginário acadêmico: escravos e trabalhadores na historiografia brasileira desde os anos 1980". In: Cadernos AEL, v. 14, n. 26, 2009.

${ }^{61}$ CASTELUCCI, Aldrin. A. Trabalhadores, máquina política e eleições na Primeira República. (Tese de Doutorado). Salvador: PPGH/UFBA, 2008.
} 
guardas municipais para terem direito ao trabalho nas ruas, avenidas e praças ${ }^{62}$. Fora das agremiações operárias, restava a esta parcela da classe trabalhadora usar da sua própria força para garantir sua sobrevivência e não se deixar dominar completamente pelas relações de poder instituídas pelo coronelismo. Nestes casos, as relações de trabalho quase sempre se tornavam uma questão de polícia.

Para os que estavam sob a proteção das associações mutualistas de classe, 0 tratamento era outro. Imbuídos de um perfil de trabalhador centrados na valorização do trabalho livre, no patriotismo e na busca pelo progresso, posicionavam-se dentro do princípio social regulador estabelecido pelas elites brasileiras no início do século $X X^{63}$. Foram esses sujeitos que formularam uma parte das tradições, das práticas, das crenças, em essência, das identidades que constituíram as organizações de classe dos trabalhadores livres na Bahia, inclusive fugindo da noção de classe do marxismo tradicional64. Não era possível reprimir com a polícia estes grupos organizados. Ora, era preciso, então, cativar aqueles que estavam nas entidades da classe trabalhadora, pois era interessante para as autoridades políticas assegurar a lealdade dessa mão de obra assalariada, mantendo-a distante do comunismo e constituindo um esboço de acolhimento dos trabalhadores na sociedade política e nas instituições públicas de poder. Daí, o inevitável flerte e declarações de regozijos que as autoridades expressavam quando do encontro com suas bases, encenando o teatro do paternalismo na Primeira República.

Por sua vez, os trabalhadores encenavam seu contra-teatro, entregando títulos beneméritos e rendendo homenagens aos seus "patronos", cumprindo uma deferência que deixava envaidecida as elites políticas. Na prática, queriam se legitimar diante da sociedade e cobrar a sua parte no jogo eleitoral, sob a forma de subvenções, doações e inserção na política local. Não se pode negar, inclusive, que muitas das lideranças trabalhistas se deixavam envolver pelas ligações com as autoridades locais, fazendo de suas organizações palanque para seus patronos políticos. Contudo, se contextualizarmos que estes representantes do proletariado estavam circunscritos em um contexto não industrial, predominantemente rural, situada no

62 Experiências de trabalhadores que se envolveram em conflitos com patrões e autoridades públicas foram estudadas em CARVALHO, Philipe M. S. Uma cidade em disputa: conflitos e tensões em Itabuna (1930-1948). Dissertação de Mestrado. PPGHIS/UNEB, Santo Antônio de Jesus, 2009, e em CARVALHO, Philipe M. S. "Para além das autoridades dos coronéis: poder e conflito entre patrões e trabalhadores no sul da Bahia (1912-1937)". Revista de História, 2, 1, (2010), p. 39-55.

63 CHALHOUB, Sidney. Trabalho, Lar e Botequim: o cotidiano dos trabalhadores no Rio de Janeiro da Belle Époque. Campinas, SP: Editoria da UNICAMP, 2001, p. 48. Para Chalhoub, o conceito de trabalho ganhou um valor positivo, associados com a noção de ordem e de progresso e de civilização. Desta forma, as elites esperavam obter 0 controle social dos trabalhadores, desta feita, num contexto de trabalho livre.

64 Para compreender melhor o sentido de classe operária para a Bahia, vale conferir NEGRO, Antônio Luigi. "Rodando a baiana e interrogando um princípio básico do comunismo e da História Social: o sentido marxista tradicional de classe operária". In. Friedrich Engels e a ciência contemporânea. Muniz Ferreira, Ricardo Moreno, Mauro Castelo Branco (orgs.). Salvador: EDUFBA, 2007. p. 198. 
nordeste do país e de pouca inserção das ideologias de esquerda (Comunismo e Anarquismo), cuja consciência se pautava no progresso da classe, quase numa espécie de positivismo operário, compreenderemos que os objetivos dos trabalhadores atendiam às expectativas de sua época. Diríamos que na impaciência de fortalecer a união da classe trabalhadora e de obter vantagens para manter a sobrevivência de suas associações, artistas e operários tinham a paciência necessária para tirar proveito das disputas eleitorais. Do ponto de vista historiográfico, as evidências estudadas neste artigo mostram que é possível fazer uma história social da política, em que pese à desmitificação do conceito de Coronelismo somente enquanto expressão de poder. Não podemos perder de vista as experiências dos trabalhadores e sua capacidade de avaliar as disputas eleitorais e nela desenhar suas expectativas de vantagens e de interesses na correlação de força com autoridades e patrões na década final da Primeira República.

\section{Referências Bibliográficas}

BATALHA, Claudio H. M. Cultura associativa no Rio de Janeiro. In. Cultura de classes: Identidade e diversidade na formação do operariado. Claúdio H. M. Batalha, Alexandre Fortes, Fernando Teixeira da Silva (orgs.). Campinas, SP: Ed. da UNICAMP, 2006.

Identidade da classe operária no Brasil (1890-1920): Atipicidade ou legitimidade? In. Revista Brasileira de História. São Paulo, V.12, n. ${ }^{0} 23 / 24$, set.91/ago92

CARVALHO, José Murilo de. Pontos e bordados: escritos de história e política. Belo Horizonte: Ed. da UFMG, 2005.

CARVALHO, Philipe M. S. Uma cidade em disputa: conflitos e tensões em Itabuna (1930-1948). Dissertação de Mestrado. PPGHIS/UNEB, Santo Antônio de Jesus, 2009.

Para além das autoridades dos coronéis: poder e conflito entre patrões e trabalhadores no sul da Bahia (1912-1937). In. Revista de História, 2, 1, (2010).

CASTELUCCI, Aldrin. A. Trabalhadores, máquina política e eleições na Primeira República. (Tese de Doutorado). Salvador: PPGH/UFBA, 2008.

CERTEAU, Michel de. A Invenção do Cotidiano. 1. Artes de fazer. Petrópolis, RJ: Vozes, 2008.

CHALHOUB, Sidney. Trabalho, Lar e Botequim: o cotidiano dos trabalhadores no Rio de Janeiro da Belle Époque. Campinas, SP: Editoria da UNICAMP, 2001.

; SILVA, Fernando Teixeira. Sujeitos no imaginário acadêmico: escravos e trabalhadores na historiografia brasileira desde os anos 1980. In: Cadernos AEL, v. 14, n.26, 2009.

FALCON, Gustavo. Os coronéis do cacau. Salvador: lanamá/Ed. UFBA, 1995.

FAORO, Raymundo. Os donos do poder. a formação do patronato brasileiro. $4^{\mathrm{a}}$ ed. Porto Alegre: Globo, 1977.

FORTES, Alexandre. Nós do Quarto Distrito...: a classe trabalhadora porto-alegrense e a Era Vargas. Caxias do Sul, RS: Educs; Rio de Janeiro: Garamond, 2004. 
FREITAS, Antônio F. Guerreiro. Caminhos ao encontro do mundo. Antônio Fernando Guerreiro de Freitas e Maria Hilda Baqueiro Paraíso. Ilhéus, Ba: Editus, 2001.

FRENCH, John D. Proclamando leis, metendo o pau e lutando por direitos. In. Direitos e justiças no Brasil. Sílvia Hunold Lara e Joseli Maria N. Mendonça. Campinas, SP: Ed. da UNICAMP, 2006.

GOMES, Angela de Castro. A Invenção do Trabalhismo. Rio de Janeiro: Editora FGV, 2005.

Cidadania e direitos do trabalho. Rio de Janeiro: Jorde Zahar Editor, 2002.

LEAL, Victor Nunes. Coronelismo, Enxada e Voto: o município e o regime representativo no brasil. $2^{\mathrm{a}}$ Ed. São Paulo: Ed. Alfa-Ômega, 1975.

NEGRO, Antônio Luigi. Paternalismo, populismo e história social. In. Cadernos AEL, v.11, n.20-21, 2004.

Rodando a baiana e interrogando um princípio básico do comunismo e da História Social: 0 sentido marxista tradicional de classe operária. In. Friedrich Engels e a ciência contemporânea. Muniz Ferreira, Ricardo Moreno, Mauro Castelo Branco (orgs.). Salvador: EDUFBA, 2007.

NORONHA, Sílvia Sarmento. A raposa e a águia: J.J. Seabra e Rui Barbosa na política baiana da Primeira República. Dissertação de Mestrado. Salvador: PPGH/UFBA, 2009.

POPINIGIS, Fabiane. Proletários de casaca: trabalhadores do comércio carioca, 1850-1911. Campinas, SP: Editora da UNICAMP, 2007.

SAMPAIO, Consuelo Novais. Partidos políticos da Bahia na Primeira República: uma política de acomodação. Salvador: Ed. da Universidade Federal da Bahia, 1998.

THOMPSON, E. P.. As peculiaridades dos ingleses e outros artigos. Antonio Luigi Negro e Sérgio Silva (orgs.). Campinas, SP: Ed. da UNICAMP, 2001.

Costumes em comum: estudos sobre a cultura popular tradicional. Revisão técnica Antônio Negro, Meneguelo, Paulo Fontes. - São Paulo: Companhia das Letras, 1998. 